\title{
Gender myth and the mind-city composite: from Plato's Atlantis to Walter Benjamin's philosophical urbanism
}

\author{
Abraham Akkerman
}

(C) Springer Science+Business Media B.V. 2012

\begin{abstract}
In the early twentieth century Walter Benjamin introduced the idea of epochal and ongoing progression in interaction between mind and the built environment. Since early antiquity, the present study suggests, Benjamin's notion has been manifest in metaphors of gender in city-form, whereby edifices and urban voids have represented masculinity and femininity, respectively. At the onset of interaction between mind and the built environment are prehistoric myths related to the human body and to the sky. During antiquity gender projection can be detected in western perceptions linking natural and built environments, commencing with Plato's Atlantis and his Myth of Er, and later as a likely import of the Chinese yin-yang mythology. Culminating with the Age of Discovery, alongside advances in experiential awareness of the Earth's sphericity, respective feminine and masculine earmarks can be detected in early modern perspicacity of the Earth's southern and northern hemispheres. Our conceptions of natural and built environments inherently continue to contain gender traits. Yet urban voids, as the feminine face of cityform, have been severely understated in the built environment. Through design and configuration of urban voids, allegories of femininity in city-form ought to be celebrated, not discarded.
\end{abstract}

\footnotetext{
A. Akkerman ( $\square)$

University of Saskatchewan, Saskatoon, SK, Canada

e-mail: avi.akkerman@usask.ca
}

Keywords Walter Benjamin and phenomenology of the city · Plato and Aristotle - St. Thomas More and Tomasso Campanella $\cdot$ Femininity-masculinity, yinyang and feng shui - Gender myth in discernment of northern versus southern hemisphere $\cdot$ Gender myth in discernment of edifices versus urban voids . Interaction of mind and environment

\section{Introduction}

During the closing years of the twentieth century much of the study of interaction between humans and their environments has been within the domain of natural and social sciences. Impact of humans upon their environment, often formalized in environmental impact assessments, has been within the scope of biophysical or socioeconomic studies. The reverse impact of natural or built environments upon humans has been usually judged within the realm of human ecology, and environmental psychology and anthropology.

The notion that continuous and mutual impact between contemporaneous built environment, on the one hand, and humans within it, on the other hand, ought to be counted also as a force behind the evolution of urban civilizations, is an outlook that had emerged from twentieth century psychoanalytic survey of urban edifices and spaces of Paris and Berlin, 
the unfinished Arcades Project of Walter Benjamin (1933/1999). Considered still today the foremost exponent of humanism in urban thought Benjamin broached the question of mind-city interaction, pointed specifically at the history of civilization, as a query of the occurrence and situation of humans within their built environments.

The place of humans within their environment is a point of departure in the phenomenological inquiry of perception and lived space by Maurice Merleu-Ponty (1962, 440). While Merleau-Ponty's phenomenology of lived space implies a link with the body, Benjamin's unfinished work addressed the dynamic relation between the urban environment and minds within it. But already in a 1924 speech to the Architectural Association in London Winston Churchill had popularized a notion of mind-city interaction by remarking, "we make buildings and afterwards the buildings make us" (Duffy 1974). Pointing to communication media Marshall McLuhan had paraphrased: "We shape our tools and then our tools shape us" (1964, 58-59). Erwin Panofsky (1957) showed that a factual feedback loop between mind and the built environment exists in the case of Gothic architecture and scholastic thought. More recently, reflecting on the feng shui geomancy, Yi-fu Tuan has observed cerebral impact of environmental myth in the East, occurring through generic patterns of parts reflected in a larger whole: "a single roof tile encapsulates the essential order and meaning of the Chinese cosmos. The mythical space depicted there recurs in the house, of which the tile is a part; in the city, of which the house is a part; and finally in the empire, of which the city is a part" (Tuan 2001, 100).

It is, however, Benjamin's work that provides the earliest articulation to the claim of a universal interaction pattern between mind and the built environment, as a dynamic, evolutionary progression of civilization through history. Whereas the conventional notion of environmental impact stems from contemporaneous features of natural and built environment upon or near the Earth's surface, the foundational notion of environment in the context of cerebral evolution of humans, relates to the possible origins of a mind-environment feedback progression. Such origins could be sought in qualities that are closer to, as well as much further from the human agent or observer than the "Earth's surface". The very nearest such origin is the observer's body itself-in skin and flesh—and his or her immediate human-physiological vicinity. As Merleau-Ponty intimates, the body is always the spatial origin of observer's whereabouts (Merleau-Ponty 1962, 169-170). The very furthest from a human agent are celestial features emanating from naked eye observations.

The postulation itself of continuing and mutual interaction between mind and the built environment may be less contentious than the proposition that the origin of mind-environment interaction ought to be sought in a perceptual link between the absolutely immediate and the unreachably distant of our own three-dimensional spatiality. The present inquiry shows that such a link ensues from primordial gender myths, identified by Carl G. Jung. Although Benjamin in his groundbreaking psychoanalytic survey of Parisian city-form drew on Jung's notion of the collective unconscious, during his short life he never managed to tie city-form with a projection of gender or gender myth. This study shows that gender myth is a constructive element in mind-city interaction and appears to be critical, indeed, to contemporary questions of urban design, planning, and city-form in general.

The present study attempts to be a reflection on gender projection upon the composite of city-form and the minds within it, and a new point of departure for a discourse on the conceptual groundwork laid out by Benjamin almost a century ago. The contention that mind-city interaction, in its bearing upon urban geography, planning and design, cannot be detached from gender, ought to be seen as a contribution to Benjamin's own unfinished venture, as well as arising from it.

\section{Sauer's cultural landscapes and Lowenthal's geography of memory}

The foundational premise implicit in the work of both Benjamin and Merleau-Ponty is that the built environment is an agent of cerebral change. But as a fledgling idea the contention of a feedback progression that mutates minds as well as their built environments through time could be seen emerging already from the cultural geography of Carl O. Sauer, a decade before Benjamin's work. In "The morphology of landscape," Sauer (1925) advanced the concept of a cultural landscape as the imposition of culture upon nature. 
Culture, as defined by the shared myths, beliefs and behavioral standards, manifests itself in a cultural landscape, i.e. in human intervention upon natural landscape. Culture and one of its more important aspects, technology, have been changing the lived environment of humans, primarily through considerations of expediency related to the human body, while bodily experiences have been changing accordingly and, in turn, have often driven advances of technological change. Landscapes modified by human action, as an aspect of culture, thus impact culture itself, whereby the feedback interaction between culture and landscape as a progression in time, defines much of the history of civilization. Sauer's cultural geography had set in motion a century-long discourse which in the last several decades had culminated in discussions on gender in context of city-form (Domosh 1988) and the place of gender in the production of geographical knowledge (Rose 1993).

In parallel to, but quite independent of Benjamin's earlier work, also the geographic inquiry by David Lowenthal into psychoanalytic aspects of landscape, pointed to environmental judgment and action as tied to "perceptions forged by preconception and experience, coloured by taste and preference, variegated by culture and personality, amplified by memory and diminished by amnesia. Environmental behaviour made sense only in the light of intention and feeling" (Lowenthal 1994).To Lowenthal, time and the temporal aspect of a landscape, as often manifested in nostalgia arising from the memory of the past, constitute the ingredient that gives meaning to the presence of humans within their physical environments. In a 1975 paper Lowenthal specifically addressed the shaping of physical landscapes through the myths and beliefs to which these very landscapes gave rise in the first place:

As we erode and alter the inherited past, we more and more contrive our own. Creatures of historical processes beyond our control, we shape landscapes and artifacts to conform with illusory histories, public and private, that gratify our tastes.

Extending this view, the feedback aspects and the temporal features of cultural landscapes have been further elaborated upon in The Place of Landscape, a paper by Richard Schein (1997). By viewing cultural landscapes as "discourse materialized," a provisional product of an ongoing process, Schein confers an organic, if not outright mythical interpretation to this feedback pattern, contending that there is a mutual attempt of landscapes and their inhabitants to "discipline" each other.

A powerful notion of landscape impact upon religious thought and through it also upon changing political concepts of governorship is James Duncan's extensive study of Kandyan kings and landscapes in Sri Lanka in the early 19th century. Here territorial expansion and autocratic rule are shown as becoming legitimized by viewing urban landmarks and landscapes as divine representation, much as a sacred text of a holy book. The hero-king of the Kandyan is then presented to the countryfolk as an earthly manifestation of gods, whereby both gods and kings demonstrate their power and wisdom in both the natural as well as the urban landscapes (Duncan 1990, 42-58). A significant textual component of Kandyan folklore is the cosmogony of early Hindu and Lankan myth, with the pole star and the Milky Way constituting its more significant elements (ibid., 44-51).

Presaging Lowenthal's geography of memory while also expressing the analogy of the city as a poem or a mythical text, Henri Bergson in his Introduction to Metaphysics (1924, 159-162) evokes the experience of walking through streetscapes as contrasted with viewing them in a series of snapshot photographs. Bergson's notion has been restated by Michel de Certeau (1984) in his "Walking in the City," a chapter in his book, The Practice of Everyday Life. Only through walking, the one mode of travel almost entirely overlooked by 20th century planning, can we, de Certeau argues, preserve the communal memory of urban places, thus conferring meaning to them and the streetscape enveloping them. Inevitably, it is urban void that facilitates and corresponds to movement within the city. But whereas mechanized transportation, subject to control and structured rules, constitutes mainly a conduit to buildings and other fixed structures, human gait throughout a streetscape induces spontaneity, human encounter and surprise. It is in this sense too that streetscape can be viewed as a mythical text, involving both enigma and revelation. It is on account of these considerations, much as by necessity of the tragic circumstances that cut short Benjamin's life, that as an attempt at psychoanalytic survey of urban space, the Arcades Project ought to be seen as incomplete. To more thoroughly effectuate 
Benjamin's project reflection on gender myths and environmental allegories from their early times ought to be structured within his original ideas.

\section{Gender traits in early cosmogony and city-form}

A movement presumes void, thus suggesting a feminine idiom; an edifice presupposes stability and solidity, proffering masculinity. Void and edifice, as environmental expressions of gender, appear to be grounded in primordial myth, while it is also gender from which the notions of the absolutely immediate and the unreachably distant had emanated. United in a Greek creation myth that appears to perpetuate a link between the Earth and the sky is Pandora, the first woman and the mother of all humankind. In the link between the Earth and the sky, contrasting the epitome of femininity, is the stone of omphalos, embodiment of a navel or a center, a representation of the masculine.

Pandora is the embodiment of unification of the Earth with the sky, having been molded from earth on the order of Zeus, the god of the sky. The material representation of Pandora is a jar, the containment of void. The poet Hesiod relates in Works and Days (60-105) the earliest literary version of Pandora, as a female possessing a jar of godly consignments, many of which were afflictions delivered to mankind in retribution for the theft of fire. In a subtle feminine symbolism Pandora exerts her power through the jar. Out of sheer curiosity, rather than malice, Pandora is said to have opened the jar that contained toil, sickness, disease and all other evils of mankind, releasing them all but one: hope. As a first mortal woman, she appears to attain supremacy through her femininity, somewhat akin to a priestess.

Fire, in Greek mythology, was stolen from Zeus and given to mankind by his champion, Prometheus the Titan. Zeus sent out two eagles to fly across the world to meet at its center, the "navel" of the world. This was said to be at Delphi, and the world's "navel" was marked by the stone of omphalos. Zeus then punished Prometheus for his crime by having him bound to the stone while each day one of the eagles ate his liver only to have it grow back and to be eaten again the next day.

The stone of omphalos at Delphi is the most famous of markers denoting the world's "centre." In other areas throughout the Mediterranean similar heavenly or sacred stones are found, associated mythologies sometimes linking them with meteorites, and thus, with fire (Burke 1986, 219). The gender aspect of this outlook binds sky and myths stemming from the theme of a sacred stone or the "world's navel" (axis mundi). The omphalos at Delphi marks the shrine where since early antiquity the god Apollo was believed to speak through a priestess, the oracular site going back perhaps millennia (De Boer and Hale 2000). Specifically associated with masculinity have been other sacred rocks or mountains, and commencing with the Mesopotamian ziggurat or the East-Asian pagoda, through forts and castles to contemporary skyscrapers, towering edifices have long become manifestations of masculinity in the built environment (e.g., Domosh 1988; Grosz 2001, 160). A literary testimony to such representation is in the Ulysses of James Joyce, where the 19th century Martello Tower in Dublin is said to be an omphalos.

The contrasting, feminine aspect frequently relates myths of the Earthmother with gardens, agriculture and cultivation of raw land, or with open spaces. At Çatalhöyük, a Neolithic city from 7000 BCE in the south-central part of present-day Turkey, excavated between 1962 and 1965, abundance of goddess statuettes was uncovered. Although a male deity existed as well, female deity statues far outnumber those of the male deity (Mellaart 1967, 181). All outdoor activities at Çatalhöyük seem to have been carried at rooftops of connected huts, entrances to which were through holes in the ceiling (Steele 2007). The open space at rooftops may have been used for public and ritual gatherings.

Whereas temples or shrines were used elsewhere as main places of ritual the use of open space for such a purpose is uncommon, yet evidenced also on Minoan Crete. Open spaces of the Minoan civilization, geographically near, although of a much later period than Çatalhöyük, provide evidence of a communal disposition towards the female. It was the priestess, or a cult associated with one, that appears to have inspired the Minoan civilization on Crete during the Bronze Age, c. 2700 BCE—c. 1500 BCE. The Minoan priestess ritual had been performed in sanctuaries at caves or at designed open spaces atop mountains, and archaeological finds on Crete point to a prominently gynocentric Minoan religion. The profusion of priestess statues and evidence such as a large Minoan fresco from c. 15th century BCE, showing a man and two 
women participating in the sport of bull-leaping, lend support to the belief that Minoan society was egalitarian or matriarchal (Coleman 2005). A millennium later, in classical Greece, the shrine at Delphi had followed in the Minoan female priestess tradition. Origins of the myth of the bi-sexual god Dionysus representing femininity in later classical Greece have also been traced to Minoan Crete (Kerényi 1976).

\section{Magnesia and the myth of Atlantis in Plato's cosmology}

The cult of a female priestess is echoed in the maiden Cleito of Plato's mythical, ideal city on the island Atlantis, a tale possibly inspired by legendary accounts of a Minoan metropolis on the island Santorini near Crete (Pellegrino 1991, 38-41). In his dialog Critias Plato describes concentric zones making up the city, in its midst Cleito, the future wife of the sea-god Poseidon:

And Poseidon, receiving for his lot the island of Atlantis, begat children by a mortal woman, and settled them in a part of the island which I will describe. Looking towards the sea, but in the centre of the whole island, there was a plain which is said to have been the fairest of all plains and very fertile. Near the plain again, and also in the centre of the island at a distance of about fifty stadia, there was a mountain not very high on any side. In this mountain there dwelt one of the earth born primeval men of that country, whose name was Evenor, and he had a wife named Leucippe, and they had an only daughter who was called Cleito. The maiden had already reached womanhood, when her father and mother died; Poseidon fell in love with her and had intercourse with her.

(Critias 113 b-d)

In his reference to the mythical city on Atlantis in the Critias Plato elaborates on the fortification of the city by Poseidon who

enclosed the hill in which [Cleito] dwelt all round, making alternate zones of sea and land larger and smaller, encircling one another; there were two of land and three of water, which he turned as with a lathe, each having its circumference equidistant every way from the centre, so that no man could get to the island, for ships and voyages were not as yet.

(Critias $113 \mathrm{~d}-\mathrm{e}$ )

It is not difficult to look for a cosmic parallel to the ideal city of Atlantis. The two zones of land could be seen corresponding to the celestial spheres of the innermost planets, Mercury and Venus, the only two planets that transit across the Sun, as against the three zones of water, corresponding to orbits of the remaining three planets known at the time, Mars, Jupiter and Saturn. In the account of Naomi Golding (1975), the number of enclosed land areas between and outside the five zones is seven-but on this account too Plato could have been counting in also the celestial spheres of the Moon and the Sun.

Plato's other ideal city, Magnesia, is described (Laws V, 811ce) as self-sufficient in resources so as to dampen love of money by discouraging seafaring and outside commerce. Plato described Magnesia, his ideal polis on Crete, as having 5,040 households, the entire city set on a circular plan. A cosmic link is implicit in Magnesia through the number 5,040 of households, and the apportionment of Magnesian land:

Then we divide the city into twelve portions, first founding temples to Hestia, to Zeus and to Athene, in a spot which we will call the Acropolis, and surround with a circular wall, making the division of the entire city and country radiate from this point. The twelve portions shall be equalized by the provision that those that are of good land shall be smaller, while those of inferior quality shall be larger. The number of the lots shall be 5040 [...]

(Laws V, 745c)

The number 12 corresponds to the number of Olympian gods, possibly drawing also on practices such as those from Thurii, where the monthly rotation of cultic duties was administered throughout the year. Earlier, Plato explains the territorial division in conjunction with the optimal number of households in the ideal city:

The number of our citizens shall be 5040 - this will be a convenient number; and these shall be owners of the land and protectors of the allotment $[\ldots]$ Let the whole number be first divided 
into two parts, and then into three; and the number is further capable of being divided into four or five parts, or any number of parts up to ten. Every legislator ought to know so much arithmetic as to be able to tell what number is most likely to be useful to all cities; and we are going to take that number which contains the greatest and most regular and unbroken series of divisions. The whole of number has every possible division, and the number 5040 can be divided by exactly fifty-nine divisors, and ten of these proceed without interval from one to ten [...]

(Laws V, 737e-738b)

Plato's choice of the number 12 , for subdivision of the city's land, and of the number 5,040 as the amount of household lots, in such close association with gods and oracles, alludes to Pythagorean influence upon Plato and to cosmic link sought by him for Magnesia (Livio 2002, 65-66).

\section{Gender as an inherent feature of Plato's world}

Plato's myth of Atlantis, as well as his directives for Magnesia, seem to be a prelude to his own notion of a link between mind and the city. Such a linkage is offered in his city-soul analogy, mainly throughout Book IV of the Republic, where the ideal city, as the Form of a city, is shown to be a universal paradigm shared by all mankind:

And so of the individual; we may assume that he has the same three principles in his own soul which are found in the state; and he may be rightly described in the same terms, because he is affected in the same manner.

(Republic IV, 435)

At the very conclusion of the Republic (Book X, 614-621) Plato launches an enigmatic, cosmogonic parable, the Myth of Er. It is this parable through which cosmos is linked once more and definitely to Plato's ideal city. In the fable, the soldier Er who was believed to have died, journeys to the afterlife and comes to life again to tell his story, in which the universe is shown to be a celestial spindle, the Spindle of Necessity. Placed on the Spindle of Necessity are eight whorls, constituting perfect circles:
The first and outermost whorl has the rim broadest, and the seven inner whorls are narrower, in the following proportions- the sixth is next to the first in size, the fourth next to the sixth; then comes the eighth; the seventh is fifth, the fifth is sixth, the third is seventh, last and eighth comes the second. The largest (or fixed stars) is spangled, and the seventh (or sun) is brightest; the eighth (or moon) coloured by the reflected light of the seventh; the second and fifth (Saturn and Mercury) are in colour like one another, and yellower than the preceding; the third (Venus) has the whitest light; the fourth (Mars) is reddish; the sixth (Jupiter) is in whiteness second.

(Republic X, 615b)

Plato leaves no doubt that the celestial whorls are real cosmic devices, and not a mere metaphor on the earthly spindle. The clockwork universe of the cosmic whorls appears regimented, somewhat masculine. This rigid masculine mechanism is softened by the feminine touch of the Fates, the daughters of the goddess Necessity, who assist at will in the revolution of the cosmic spindle-whorls:

[...] the Fates, daughters of Necessity, are clothed in white robes and have chaplets upon their heads, Lachesis and Clotho and Atropos, who accompany with their voices the harmony of the sirens-Lachesis singing of the past, Clotho of the present, Atropos of the future; Clotho from time to time assisting with a touch of her right hand the revolution of the outer circle of the whorl or spindle, and Atropos with her left hand touching and guiding the inner ones, and Lachesis laying hold of either in turn, first with one hand and then with the other.

(Republic X, 618a-b)

In his mythical account of creation by the demiurge, Plato traces the origin of the universe to a primordial compound. In what is likely a reference to the intersections of great circles of the ecliptic and the celestial equator (Cornford 1966, 73), Plato says:

The entire compound was divided by him lengthways into two parts, which he united at the centre like the letter $\chi$, and bent into an inner and outer circle or sphere, cutting one another again at a point over against the point at which 
they cross. The outer circle or sphere was named the sphere of the same - the inner, the sphere of the other or diverse; and the one revolved horizontally to the right, the other diagonally to the left.

(Timaeus 36b6)

Plato's assertion regarding the crossed cosmic circles was related to astronomic observations of the path of the ecliptic and the celestial equator as known in classical Greece also from Mesopotamian sources, some two thousand years before Plato.

In Book V of the Republic (451b-457b) Plato appears to advocate equality for women, implying they could or should be part of the guardian class, and that women should engage in music and gymnastics. The Republic is the erudition of the guardians, the philosopher-kings, of the ideal polis. The Myth of Er, at the closing of the entire ten-book treatise, would therefore seem to carry a final, underlying message to intellectual and political elites of the Republic. Quite consistent with frequent physical alignment of prehistoric cities with the North Star (or with cardinal directions), Plato appears to draw analogy, both in the story of Atlantis as well as in the Myth of Er, between the universe and the ideal city. The bond of the ideal city with the cosmos, as the orderly universe, seems to be Plato's final message in the Republic.

\section{Antarktikos and the Antichthones: first hemispheric inquiries}

Plato's model of the universe, the spindle-whorl, is in the form of "upper" hemispheres only. In addition, as a spindle-whorl, this "upper" hemispheric model appears to be mechanical, "masculine," save the action of the Fates, the daughters of Necessity, who assist at will in the revolution of the hemispheres. The outstanding, implicit, question that Plato seems to leave open, is, What then is the nature of the universe's "lower" hemispheres, and who is assisting in their operation?

The description of the cosmic $\chi$ in the Timaeus precedes a discussion with an obscure exposition on three founding elements of the world, each such element in two varieties: divisible and indivisible. The three founding elements are Sameness, Difference and Being (or Existence). The two cosmic circles, crossed in the image of the letter $\chi$, are seen by Plato as created from action upon the three founding elements, whereby the demiurge imparts on the circles a rotary movement about their axes (34c-36c). Parallelism with the three Fates in the Myth of Er is most likely and deliberate (Taylor 1928). If Plato's parallelism had been, indeed, intended, inevitably also the underlying view of Plato in his message is that femininity and masculinity are ingrained in the structure of the universe itself.

In the Timaeus (29b-34b), Plato describes the world as a living creature with a soul (rather than a mechanism) and the demiurge, a world craftsman, a supernatural masculine figure using three inanimate elements, Balance, Difference and Being, to create order out of the primordial, disordered substance of the world, shapeless, mixed and in an unpredictable, persisting motion. With a modicum of effort one could find a masculine-feminine parallel between the model of the universe in the Myth of Er and the one in the Timaeus. Flair of Dionysian capriciousness, unpredictability or femininity, seems to emerge from such a parallel for the "lower" hemispheres of the universe that must be ruled in by the demiurge. And analogous to the goddess Necessity and her three daughters in control of the "upper," mechanical, Apollonian hemispheres of the universe, the male demiurge, that could be none other than the Sky Father, extends his control over the universe's "lower" hemispheres through his three inanimate elements.

The parallelism between the clockwork "upper" hemisphere and the whimsical "lower" hemisphere of the universe throws light on the attitude forming also towards the southern terrestrial hemisphere in Plato's time. While sphericity of the Earth has been put forward already by Pythagoras, evidence of Plato's belief in the spherical shape of the Earth is his own assertion in the dialogue Phaedo (110b) that, seen "from above," the Earth appears like a twelve-paneled globe, a dodecahedron (Couprie 2005).

According to Cicero's account (in Tusculan Disputations XIV) creator of the first celestial globe was the astronomer Eudoxus of Cnidus (c. 410-347 BCE). A scholar at Plato's Academy, Eudoxus would have been inevitably cognizant of the southern celestial hemisphere. Platonic perception of the southern celestial hemisphere seems also to correspond to early beliefs regarding the universe and the Earth. Dating to early Greek myth the Earth was perceived as encircled 
by the vast river Oceanus (e.g., Homer's Odyssey XII. 1; Illiad XVIII, 399; XXI, 194) while, according to the early historian Diogenes Laertius, Pythagoras was "the first who called the earth round; though Theophrastus attributes this to Parmenides, and Zeno to Hesiod" (Life of Pythagoras XXV). In Greek mythology and religion flowing water conferred feminine qualities (Harrison 1922, 257-321), and such attribution seems to confirm yet again the feminine flair in the Platonic discernment of the southern celestial hemisphere.

Explicit parallelism between northern and southern terrestrial hemispheres had been articulated only by Aristotle (384-322 BCE), Plato's student. In his Meteorologica Aristotle gives account of the Earth's "known," northern hemisphere, and its "unknown," southern hemisphere along with the hypothetical southern continent of Antarktikos. The parallelism stated by Aristotle assumes five geographic zones to the Earth, the torrid zone enveloping the Equator from both its northern and southern sides, the frigid zones enveloping the northern and southern poles of the globe, and the temperate zones lying at the opposite hemispheres of the globe, between the frigid and the torrid zones (Meteorologica 362 a31-35). The frigid and torrid zones are entirely uninhabitable, while the inhabited part of the temperate zone in the northern hemisphere is referred to as the Oikoumene.

Parallelism between the hemispheres of the universe and those of the Earth could be sought in the reference to the "inhabitants" of the southern hemisphere, i.e. those who occupy places that are antipodes of the northern hemisphere. As reported by Strabo, inhabited land in the southern hemisphere's temperate zone had been assumed by Crates of Mallus, in his construction of the first terrestrial globe, in the 2nd century BCE (Geography I, 2.24). The first explicit mention of hypothetical inhabitants of the southern hemisphere was not until the year $43 \mathrm{CE}$, in Book I of De chorographia of the Roman geographer Pomponius Mela:

The earth also is divided from east to west into two halves, which they term hemispheres, and it is differentiated by five horizontal zones. Heat makes the middle zone unlivable, and cold does so to the outermost ones. The remaining two habitable zones have the same annual seasons, but not at the same time. The Antichthones inhabit one, we the other.

(Romer 2001, 34)
The habitat of people hypothesized as living on the southern hemisphere, however, had not become a subject of query for over a millennium. With European voyages during the Age of Discovery such proposition had emerged with the new notion of the ideal city in Thomas More's Utopia.

\section{Gender and geography in Thomas More's Utopia}

Utopia, an imaginary account of people and their habitat "under the equator" by St. Thomas More was first published in 1516. More's fabled island of Utopia, an early Renaissance inspiration from Plato's Atlantis, has its capital the ideal city Amaurot. Permeated with gardens shared along with other property among all citizens, Amaurot is described as a city of open spaces rather than mere buildings, communalism and altruism of the society, rather than its ruling hierarchy, and thus, More's ideal society lends a feminist flair to his Utopia (Jones and Seibel 1978).

Utopia had become a celebrated fiction in sixteenth and seventeenth centuries' continental Europe, and soon also an epithet to all notions of ideal communities. More was likely unaware of the works by his European contemporaries, such as the proposal by Antonio Averlino Filarete for an ideal city, Sforzinda, in his Trattato di Architettura (c. 1465). But the overall cultural context of the time was not lost on him, and Utopia has been usually viewed as a satire on contemporaneous English society. On his imaginary island there were 54 cities almost identically designed after Amaurot, the capital. Amaurot itself

lies up against a gently sloping hill; the town is almost square in shape [...] The streets are conveniently laid out for use by vehicles and for protection from the wind. Their buildings are by no means paltry; the unbroken rows of houses facing one another across the streets through each ward make a fine sight. The streets are twenty feet wide [...]

(Utopia II)

Harmony also guided the civic programme of Utopia, where More touched upon such modern concepts as optimal city size and transportation within the context of agricultural production and labour.

Agriculture is prevailing on Utopia, where also everyone is taught farming and is expected to live and 
work in the countryside for at least 2 years, women engaged in the same work as men. Within households, wives have about the same status as their husbands even though women are responsible for most household errands.

Along with these features, feminist relative to sixteenth century's standards, More identifies the geographic location of Utopia

Under the equator, and as far on both sides of it as the sun moves, there lay vast deserts that were parched with the perpetual heat of the sun; the soil was withered, all things looked dismally, and all places were either quite uninhabited, or abounded with wild beasts and serpents, and some few men, that were neither less wild nor less cruel than the beasts themselves. But, as they went farther, a new scene opened, all things grew milder, the air less burning, the soil more verdant, and even the beasts were less wild: and, at last, there were nations, towns, and cities, that had not only mutual commerce among themselves and with their neighbours, but traded, both by sea and land, to very remote countries.

(Utopia II)

A voyage "under the equator," much as to the New World, would have been among the most galvanizing ideas through the Age of Discovery, with navigation, and thereby also astronomy and astrology, becoming much sought disciplines of study. Alchemy and astrology had utilized names and symbols of planets, adopting the medieval explanation of the shield and spear as a symbol of the Roman god of war, Mars, and the goddess' looking glass as a symbol for Venus, the Roman goddess of love and beauty. The medieval symbols of planets are, in fact, traceable to classical Greece with the letter Theta for Thouros, or Greek for Mars, and the letter Phi for phosphoros, the god associated with the morning star, i.e. Venus (Stearn 1962).

Prevailing belief associating Mars with the North had emerged from early European myth, as for example, in the case of Thor (Mars), the mighty god of thunder, and the husband of the goddess Sif (Venus) in Norse mythology. In an allegory of beauty and courage the Renaissance painting (1483) of Sandro Boticelli shows Venus, emerging from the sea or ocean, and Mars. The early mythical bond of Mars with the North, and of Venus with the ocean, suggests also a symbolic analogy between Venus and the South.
Such symbolic relation would have been receptive by More who in his poetic epigrams "emphasizes the mutuality of the interest between Venus and Mars" (Perry 1985).

The convention that North is represented at top of a map, or in the upward direction, and South at the map's bottom, or in the downward direction, was established in the second century BCE by Claudius Ptolemy, and had been adopted, with some exceptions, by later European cartographers (Bagrow and Skelton 2010, 73-105). More's cultural milieu would have therefore likely identified the upward-pointing Mars symbol, as indicating north direction, and almost as if toward the North Star (at the latitude of England), and the downward-pointing symbol of Venus, as showing southward direction. Two centuries later similar expediency led the Swedish naturalist Carl Linnaeus (1707-1778) to apply the very same two symbols in his Systema Naturae (1735) as designating the male and female gender, respectively.

The implication of femininity as associated with the southern hemisphere, Utopia's location, lends also certain consistency to the view that, in the southern hemisphere, humans have been associated, more often than not, with pastoralist, frequently egalitarian, communities. Progression from nomadic settlements, into prehistoric forts and towns, and a patriarchal society in the northern hemisphere, on the other hand, has been propounded already by the early Arab historiographer Ibn Khaldun (1332-1406) in his Prolegomena.

\section{The geomancy of feng shui as an Eastern source in European urban thought}

One of the most significant early influences of More's Utopia was the City of the Sun by Tomasso Campanella (first published 1602). In his ideal city Campanella had his solarians make alliance with the Chinese. But Chinese leverage in Campanella's ideal city seems to go much deeper than a superficial pact. Since the late Middle Ages Chinese sway upon Europe had become apparent, most famously in the advent of gun powder and paper. China's clout in European urban thought, however, may have been primarily through Campanella's City of the Sun.

Chinese influence on Camapanella appears to be through principles in city layout guided by what 
appears to be the geomancy of feng shui. In early China the encircled, or squared, cross denoted the emperor's location at the centre of the world, shown as the meeting point of the four cardinal directions. Implicit here too is an analogy with the North Star and the skies spinning round it. The masculine view of the Chinese myth is embedded also in the notion of world's pillars: The Song Shan Mountain is said to be at the centre of the world, along with the four other mountains, Tai Shan (East), Heng Shan Bei (North), Hua Shan (West) and Heng Shan Nan (South). The Five Pillars of the world come in parallel to the Five Elements of which the world is made, according to Taoist belief, and the five planets known at the time, with the entire belief system linked to the divination of feng shui (Moore 1967). As an environmental myth the feng shui alleges aesthetic as well as utilitarian principles in optimal site selection and object configuration. Access to the Emperor's palace at the Forbidden City in Beijing is from the south, thus placing the Emperor as an earthly likeness of the North Star round whom the heavenly sphere revolves. In the twentieth century the feng shui geomancy has received increasing attention in environmental design, enjoying still today an impressive commercial success in architecture and landscaping.

The related yin/yang principle found its way to the psychoanalysis of Carl Jung who had employed it in introducing the notion of Anima and Animus (Papadopoulos 1992, 19; McGowan 1994). The yin/ yang is a belief in two mutually complementary forces as the underlying substance of the universe, yin being the feminine, passive, and downward seeking force, yang being the masculine, active, bright and upward seeking force. Yin and yang are jointly reciprocal, interdependent, gradually mutating or flowing into each other, rather than constituting absolute contrasting elements. The conceptual origin, and the cosmic connotation, of the yin/yang pair of concepts can most likely be sought in the universality of change between day and night, but their significance to the feng shui geomancy ought to seen in their literal meaning, yin standing for "shady place", and yang standing for "sunny place."

While it is More's Utopia that appears to have influenced Campanella's social and political structure envisaged for the City of the Sun, the layout of the ideal city as a cosmic analogy is the mark of Plato's Atlantis, but also of classical Chinese urban planning.
Campanella wrote his book upon a brief respite from a Rome prison in 1595, shortly after Domenico Fontana, under pope Sixtus V (during the years 1585-90), significantly redesigned the city. Whereas Fontana carved four avenues to radiate from Rome's Santa Maria Maggiore Church, Campanella encircled the four main avenues of his ideal city, similar to the Chinese plan focused on the meeting point of the four cardinal directions. Campanella's vision in the City of the Sun, perhaps also referring to Rome's seven hills, was of

a hill upon which the greater part of the city is situated $[\ldots]$ The city is divided into seven large circuits, named after the seven planets. Passage from one to the other is provided by four avenues and four gates facing the four points of the compass $[\ldots]$ the entire city is two miles and more in diameter and has a circumference of seven miles

(Donno 1981, 7-27).

In his essay, "Ptolemy and Vitruvius" (2003) Denis Cosgrove points to a historical link between representations in urban geography and descriptive cosmography, that has lasted from antiquity to the middle ages. Cosgrove stops short of pointing to parallelism between the urban grid patterns, from Hippodamus to Vitruvius, and the grid patterns of parallels and meridians, from Ptolemy to Mercator. Campanella, through the orthogonal layout superimposed upon a radial plan, appears to have put forward just such universalist parallel between his ideal city and the cosmos. The affinity in the layout of Campanella's City of the Sun with classical Chinese urban planning give further affirmation to Cosgrove's outlook, much as they appear to lend some support to anti-Eurocentric claims in the history of ideas and civilization (e.g., Hobson 2004, 116-133).

\section{Walter Benjamin and Carl Jung: the ideal city versus the authentic street}

The impact of Campanella's City of the Sun had echoed into the twentieth century leaving its mark on early Soviet architecture (Lodder 1993). Sympathetic attitude towards the Soviet Union was commonplace among Europe's intellectuals prior and during WWII, and Benjamin views on modernity, too, were aroused 
by the art and architecture of socialist realism (Ferris 2004, 19). Benjamin's series of observational essays, commenced in the Arcades Project, was unsurprisingly tainted with a Marxist outlook. Benjamin's later dissociation from Marxism, documented in his 1940 pamphlet, On the Philosophy of History (Ferris 2008, 130-135), however, had never been absorbed into his urban concepts. But already in his Arcades Project Benjamin had developed an independent, entirely nonMarxian position leading him to suggest that civilization re-creates its own environments through ideal images of earlier ages. It is also due to this process, according to Benjamin, that twentieth century cityform had emerged:

In the dream in which every epoch sees in images the epoch that follows, the latter appears wedded to elements of ur-history [...]. Its experiences, which have their storage place in the unconscious of the collective, produce, in their interpenetration with the new, the utopia that has left its trace behind in a thousand configurations of life from permanent buildings to ephemeral fashions.

(Benjamin, quoted in Buck-Morrs 1990, p. 114)

By drawing on Carl Jung's notion of the collective unconscious, Benjamin observes "elements of urhistory" ingrained in a progression of reciprocal, mutual impact with contemporaneous city-form, perpetually yielding newfangled concepts of an ideal city, and stamping their newly shared communal vision of a utopia upon the very same city-form, breeding ever new configurations of urban objects, "from permanent buildings to ephemeral fashions."

In Benjamin's eyes a manifestation of the "unconscious of the collective" since antiquity has been the street. Cultic rituals on the Italian peninsula were the custom in the founding of cities already in the Etruscan period (c. $700 \mathrm{BCE}$ ) and continued to be the practice for almost a millennium, throughout much of the Roman Empire. Fabled founders of cities in Greek mythology are often deified heroes, and within newly founded Greek colonies streets had often been called after deities. To Benjamin the street since antiquity, and to our own times, has been a medium through which minds generate images and thoughts:
Streets are the dwelling place of the collective. The collective is an eternally restless, eternally moving essence that, among the facades of buildings endures, experiences, learns, and senses as much as individuals in the protection of their four walls. For this collective the shiny enameled store signs are as good and even better a wall decoration as a salon painting is for the bourgeoisie. Walls with the "defense d'afficher" are its writing desk, newspapers are its libraries, letterboxes its bronzes, benches its bedroom furniture - and café terraces the balcony from which it looks down on its domestic concerns after work is done.

(Benjamin 1933/1999, 423).

Benjamin identifies two elements that set in motion the interaction of minds and their built environment: The one is the myth of an ideal urban world; the other is the authentic, unadulterated space of the city street. Benjamin's hybrid of city-form and the minds within it is an unusual blend of psychoanalysis with urban analysis.

In envisaging a single hybrid of city-form and minds within it, Benjamin, furthermore, makes a conjecture of a philosophical nature by putting forward the notion of a continuous mutual impact between the street, as a perceptual emblem of contemporaneous built environment, on the one hand, and human minds within it, on the other hand. It is this interaction that constitutes forceful dynamics behind the evolution of urban civilizations. Lewis Mumford, in his chapter 'The Myth of Megalopolis' in his book, The City in History (1961, 525-46) presented a similar idea as a gap between actual social or physical space of the city and the universal, albeit imaginary, notions of an ideal city.

In observing the condition of individuals within twentieth century's urban environments Benjamin had focused on human interaction with the city's edifices, and voids between or within them. The mind-city feedback that Benjamin envisages consists of mutual and continuing metamorphoses of ideal-city myth and authentic city-form. City-form mutates when the myth of an ideal city is brought to bear upon it, while the myth of the ideal city transforms itself in the same feedback process when a new city-form emerges. The contemporary city, on Benjamin's view, is the result of just such feedback loop, ongoing throughout history (Akkerman 2009). 


\section{Hemispheric projection of gender and the contemporary city}

In a critique of contemporaneous social conditions femininity is addressed by Benjamin through "the mannequin and the prostitute [...] as emissaries of a whole system of exploitation, reification, alienation" (Leslie 2006, 99). But if myth is seen as permeating outlooks of humans, then no less legitimate feminine representation is Dionysian symbolism. One abiding Dionysian enactment throughout the ages has been intoxication and ecstasy. In the final section, "To the Planetarium," of his One Way Street written in 1928 (Ferris 2008, 75-77) Benjamin noted:

Nothing distinguishes the ancient from the modern man so much as the former's absorption in a cosmic experience scarcely known to later periods. [...] All the same, the exclusive emphasis on an optical connection to the universe, to which astronomy very quickly led, contained a portent of what was to come. The ancients' intercourse with the cosmos had been different: the ecstatic trance.

Not only is this a critique of the technological civilization that had led to WWI, but it is also a clear expression of admiration of Dionysian rites, long rejected by modes of thought that had led to this civilization exactly.

Benjamin's views on intoxication and drugs, portending one of the most contentious issues in the postindustrial city, have been recently juxtaposed with his imagined, yet plausible at the time, arrival in South America (Herlinghaus 2010). Contemporaneous bond between narcotics and South America is clearly obvious, but the more subtle implication linking insobriety, a Dionysian attribute, with the southern hemisphere is noteworthy precisely due to its representation in myth.

Juxtaposing the hemispheric south with Benjamin's attitude on intoxication ought to be thus seen also in the context of 2,000 years of antipodean myths that have played a significant role in the religion, travel literature, exploration and colonization emanating from Europe (Arthur 2007). There has been a venerable claim that Eurocentrism, along with colonial and masculine biases associated with it, have been historically the essence in representations of north-hemispheric supremacy epitomized, most and foremost, by much of traditional cartography (e.g., Maddrell 1998). Northern positioning of maps, the centering of Europe in cartographic projections of the world, or cartographic diminution of geographic regions in correspondence to their proximity to the equator are the most frequent objections cast against masculine and Eurocentric biases in the history of map-making (e.g., Harley 1988).

Foreshadowing feminist and anti-colonialist critiques that were yet to follow in geography, was the Air-ocean world projection of Buckminster Fuller, introduced in the March 1, 1943, issue of Life magazine. Perhaps a brilliant extension of Plato's vision of the Earth as dodecahedron, Fuller's dymaxion world map was icosahedron, a sphere whose surface of 20 identical, equilateral triangular faces, was laid flat on a horizontal surface. Distortion due to spherical projection was minimized in Fuller's icosahedral net that displayed oceans as a contiguous body of water surrounding Antarctica at the centre, with other continents dispersed accordingly. In his book Critical Path (1982, 183-194) Fuller claimed advantage to his dymaxion projection in that it did away with what he saw being prejudicial views of verticality, "up" and "down", as representations for Heaven above and Hell below, advanced by organized religion (p. 43). Cartography met habitat design in Fuller's 1951 patent of his geodesic dome where the dymaxion frame was shown to be the optimum structure maximizing volume at minimum shell, containing "more for less" (Gorman 2005, 41-48).

Habitat design as linked with antipodean myth through gender projection has been addressed in a recent work of Deborah White. Going to the extent of identifying Australia as a "woman" White points out that, quite contrary to the characterization of her continent, feminine expression as well as Australian Aboriginal tradition in material culture seem to be suppressed in Australian built environment, and absent in its mainstream architecture (White 2001, 179-200). The masculine features of the Australian city are thus shown to be in particular contradiction with the femininity of its continental-hemispheric location.

A likeness of the mythical omphalos stone, masculinity has been viewed expressed not only in skyscrapers but in most other urban structures (White 2001, 100-134). Feminist critique of contemporary city-form could hardly find a better target of its 
censure than what has often been paraded as the symbol of architectural femininity—-the Sydney Opera House. Within contemporary built environment the femininity of the shell-shaped Sydney Opera House, a mid-twentieth century masterpiece designed by the (North-European) architect Jørn Utzon, has been usually juxtaposed specifically against the monumental steel Harbour Bridge nearby. But this fairly unique example of architectural symbolism of femininity versus masculinity is the result of the mutual proximity and union of two contrasting structures, both quite exceptional. In itself, however, the Opera House is a masculine production of a feminine symbol, and far from commonplace. Femininity representation in past or present-day urban constructions, are indeed, infrequent.

Masculinity and femininity can be discerned only in association with one another. But so, too, city and minds within it ought to be perceived jointly, in context of their mutual interaction. Gender myth and city-form are an intertwined amalgam, and perhaps only one aspect of the mind-city composite. The supposition that since archaic times myth has been a continuing driving force in the mind-city dynamics affirms contemporary views on the inherently masculine construction of geographic space throughout history. A corollary of this premise is not only the indictment by geographers led by Gillian Rose (1993) to the effect that human production of space as well as geographic knowledge, have historically suffered from a masculine bias. As a complement to the nascent work of Walter Benjamin such stance leads also to the corresponding call for recognition of feminine urbanist metaphors as a requisition of cityform.

\section{Conclusion and implications}

Commonplace representation of femininity within city-form is not in urban edifices and fixtures, but in urban voids. In Jung's psychoanalysis the collective unconscious intertwines masculine and feminine aspects of mind. Each male carries within him a feminine aspect, the Anima, while each female carries within her a masculine aspect, the Animus. As an ongoing spatial product of myth and the environment, city-form too contains aspects of both femininity and masculinity. In a vein analogous to Jung's notion, masculine and feminine aspects of the built environment can be viewed as intertwined in tangible modes of city-form. Since antiquity to this day, feminine representations of city-form could be specifically perceived in voids such as streets, squares, parks, urban river corridors, alleyways and gaps between buildings (Akkerman 2006).

Benjamin's own view on contemporaneous cityform is, by the nature of his own tragic circumstances, incomplete, as "Benjamin accumulates textual details about the city but resists absorbing them into a systematic theory or model" (Patke 2000). But consistent with Benjamin's discernment of urban fixtures and edifices as representing as well as acting upon the concomitant mindset, is the claim that structures by their very nature symbolize masculinity (Domosh 1988). Benjamin's repeated attention to the streetscape, the most commonplace of all urban voids, points in fact to a much needed emphasis on void in urban design as an expression of feminine disposition in city-form.

It is emblematic that contemporary urban problems have much less to do with the design or architecture of buildings, than with open urban spaces and their configuration: traffic congestion on roads, crime in streets and public spaces, unsightly parking lots and "brownfields," urban infrastructure and its maintenance, or lack thereof. It seems to be, precisely, the masculine emphasis on fixed structures that devalues the significance of urban voids in city-form. In order to confer a feminine facet upon city-form, the attitude to urban voids cannot be as mere conduits for, or gaps between buildings, but it must become the primary subject of civic design and urban planning inquiry. Gender myth ought to be recognized as a foundational and critical, albeit obscure, ingredient of city-form.

The acknowledgment and discernment of gender symbolism in myth, projected upon the arrangement of structures and voids, as a significant aspect in the evolution of city-form, might help address problems associated with urban space, even if not resolving them at once. In the contemporary city, spaces, their usage and carrying capacity, or underutilization, are increasingly contributing to the sense of urban dysfunction. But such observation seems to confirm the historical neglect in urban voids, on account of the emphasis on edifices.

Much urban analysis until recently has addressed utility, ideology, social and economic issues, or even religion, but has seldom dealt directly with myth and 
the human unconscious. It is yet to be shown whether myth has been the main linkage between the mind and city-form. Gender link of myth with design, construction and configuration of objects constitutes, indeed, a particularly germane subject in contemporary social and urban discourse. Furthermore, Benjamin's insinuation of an epochal feedback progression between mind and the built environment, as an aspect of the history of ideas, and of the evolution of urban environments, ought to be seen as a fundamental issue in the cultural and intellectual sustainability of the city. Yet these topics have so far lingered almost entirely unexplored.

The threefold association between gender, myth and built environments, can be envisaged as yielding a powerful reciprocal unfolding of city-form and the minds within it. The polis and mythology of the Greeks are early examples of such, pointing further to their own prehistoric origins. The humble recognition that myth, rather than sole rationality, has been a driving force behind city-form since the dawn of history could help bring a much needed paradigm-shift to urban geography, planning and design. There could be no better tribute to Walter Benjamin's unfinished project.

Acknowledgments Thanks are due to Daniel Sui and to two anonymous referees of this Journal for their valuable comments on the earlier versions of this study.

\section{References}

Akkerman, A. (2006). Femininity and masculinity in city-form: Philosophical urbanism as a history of consciousness. Human Studies, 29(2), 229-256.

Akkerman, A. (2009). Urban void and the deconstruction of neo-platonic city-form. Ethics, Place and Environment, 12(2), 205-218.

Arthur, P. (2007). Antipodean myths transformed: The evolution of Australian identity. History Compass, 5(6), 1862-1878.

Bagrow, L., \& Skelton, R. A. (2010). History of cartography. New Brunswick, NJ: Transaction.

Benjamin, W. (1933/1999). The Arcades Project (H. Eiland \& K. McLaughlin, Trans.). Cambridge, MA: Belknap Press.

Benjamin, W. (1940/2009). On the concept of history. New York: Classic Books America.

Bergson, H. (1924). The creative mind: An introduction to metaphysics. New York: Citadel Press.

Buck-Morrs, S. (1990). The dialectics of seeing: Walter Benjamin and the Arcades Project. Cambridge, MA: MIT Press.

Burke, J. G. (1986). Cosmic debris: Meteorites in history. Los Angeles: University of California Press.
Coleman, K. S. (2005). Who's afraid of 'the goddess stuff'? Feminist Theology, 13(2), 217-237.

Cornford, F. M. (1966). Plato's cosmology: The Timaeus of Plato. London: Routledge \& Kegan Paul.

Cosgrove, D. E. (2003). Ptolemy and vitruvius: Spatial representation in the sixteenth-century texts and commentaries. In A. Picon \& A. Ponte (Eds.), Architecture and the sciences: Exchanging metaphors (pp. 20-51). New York: Princeton Architectural Press.

Couprie, D. L. (2005). Some remarks on the Earth in Plato's Phaedo. Hyperboreus, 11(2), 192-204.

De Boer, J. Z., \& Hale, J. R. (2000). The geological origins of the oracle at Delphi, Greece. Journal of the Geological Society, 171, 399-412.

De Certeau, M. (1984). Walking in the city (Ch. 11). In: The practice of everyday life (pp. 102-118). Berkeley: University of California Press.

Domosh, M. (1988). The symbolism of the skyscraper: Case studies of New York's first tall buildings. Journal of Urban History, 14(3), 320-345.

Donno, D. J. (1981). The city of the sun: A poetical dialogue by Brother Tommaso Campanella. Berkeley: University of California Press.

Duffy, F. (1974). Office design and organizations: 1 . Theoretical basis. Environment and Planning B, 1(1), 105-118.

Duncan, J. S. (1990). The city as text: The politics of landscape interpretation in the Kandyan Kingdom. Cambridge: Cambridge University Press.

Ferris, D. S. (2004). The Cambridge companion to Walter Benjamin. Cambridge: Cambridge University Press.

Ferris, D. S. (2008). The Cambridge introduction to Walter Benjamin. Cambridge and New York: Cambridge University Press.

Fuller, R. B. (1982). Critical path. New York: St. Martin's Press.

Golding, N. (1975). Plato as city planner. Arethusa, 8(2), 359-371.

Gorman, M. J. (2005). Buckminster Fuller: Designing for mobility. London: Thames \& Hudson.

Grosz, E. A. (2001). Architecture from the outside: Essays on virtual and real space. Cambridge, MA: MIT Press.

Harley, J. B. (1988). Maps, knowledge and power. In: D. Cosgrove \& S. Daniels (Eds.), The iconography of landscape (pp. 272-312). Cambridge and London: Cambridge University Press.

Harrison, J. E. (1922). Prolegomena to the study of Greek religion. Cambridge: Cambridge University Press.

Herlinghaus, H. (2010). In/comparable intoxications: Walter Benjamin revisited from the hemispheric South. Discourse, 32(1), 16-36.

Hobson, J. M. (2004). The eastern origins of western civilisation. Cambridge and New York: Cambridge University.

Jones, J. P. \& Sellers Seibel, S. (1978). Thomas More's feminism: To reform or re-form. Albion (Quincentennial essays on St. Thomas More) 10(Suppl), 67-77.

Kerényi, K. (1976). Dionysos: Archetypal image of indestructible life. Bollingen: Princeton.

Leslie, E. (2006). Ruin and rubble in the arcades. In B. Hanssen (Ed.), Walter Benjamin and the Arcades Project (pp. 87-112). New York: Continuum International.

Livio, M. (2002). The golden ratio: The story of phi, the world's most astonishing number. New York: Broadway Books. 
Lodder, C. (1993). Lenin's plan for monumental propaganda. In M. C. Bown \& B. Taylor (Eds.), Art of the soviets: Painting, sculture and architecture in a one-party state, 1917-1992 (pp. 16-32). Manchester: University of Manchester Press.

Lowenthal, D. (1975). Past time, present place: Landscape and memory. Geographical Review, 65(1), 1-36.

Lowenthal, D. (1994). Author's response (to David N. Livingstone's, Classics in human geography revisited-Lowenthal, D. (1961). Geography, experience and imagination: Towards a geographical epistemology. Annals of the Association of American Geographers, 51(3), 241-260). Progress in Human Geography, 18(2), 213-215.

Maddrell, A. M. C. (1998). Discourses of race and gender and the comparative method in geography school texts, 1830-1918. Environment and Planning D: Society and Space, 16(1), 81-103.

McGowan, D. (1994). What is wrong with Jung?. Buffalo, NY: Prometheus Books.

McLuhan, H. M. (1964). Understanding media: The extensions of man. New York: McGraw Hill.

Mellaart, J. (1967). Catal Huyuk: A neolithic town in Anatolia. New York: McGraw-Hill.

Merleau-Ponty, M. (1962). Phenomenology of perception, translated from the French by Colin Smith. New York: Humanities Press, and London: Routledge \& Kegan Paul.

Moore, C. A. (1967). The Chinese mind: Essentials of Chinese philosophy and culture. Honolulu: University of Hawaii Press.

More, S. T. (1516/2001). Discourses of Raphael Hythloday, of the best state of a commonwealth. In Utopia, new translation with an introduction by Clarence H. Miller. New Haven, CT : Yale University Press.

Mumford, L. (1961). The city in history: Its origins, its transformations, and its prospects. London: Secker and Warburg.

Panofsky, E. (1957). Gothic architecture and scholasticism. New York: Meridian Books.
Papadopoulos, R. K. (1992). Carl Gustav Jung: Critical assessments. London and New York: Routledge.

Patke, R. S. (2000). Benjamin's Arcades Project and the postcolonial city. Diacritics, 30(4), 3-14.

Pellegrino, C. (1991). Unearthing Atlantis: An archaeological odyssey. New York: Vintage Books.

Perry, K. (1985). Blind Saturn: The astrological epigrams as records of More's cultural conservatism. Moreana, 22(86), 44-60.

Romer, E. R. (2001). Pomponius Mela's description of the world. Ann Arbor: University of Michigan.

Rose, G. (1993). Feminism and geography: The limits of geographical knowledge. Minnepolis: University of Minnesota Press.

Sauer, C. O. (1925). The morphology of landscape. University of California Publications in Geography, 2(2), 19-53.

Schein, R. H. (1997). The place of landscape: A conceptual framework for interpreting an American scene. Annals of the Association of American Geographers, 87(4), 660-680.

Stearn, W. T. (1962). The origin of the male and female symbols of biology. Taxon, 11(4), 109-113.

Steele, L. D. (2007). The Neolithic settlement at Catalhoyuk and Pueblo ethnoarchaeology. Building communities: House, settlement and society in the Aegean and beyond. In R. Westgate, N. Fisher \& J. Whitley (Eds.), Proceedings of a conference held at Cardiff University, 17-21 April 2001, British School at Athens Studies 15 (pp. 37-46). London: British School at Athens.

Taylor, A. E. (1928). A commentary on Plato's Timaeus. Oxford: Clarendon Press.

Tuan, Y.-F. (2001). Space and place: The perspective of experience. Minneapolis: University of Minnesota.

White, D. (2001). Masculine constructions: gender in twentiethcentury architectural discourse-'Gods', 'Gospels' and 'tall tales' in architecture. Unpublished Ph.D. dissertation. Adelaide: University of Adelaide. 